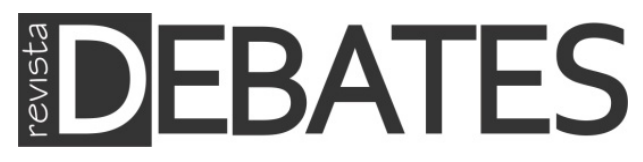

\title{
Meditations on The Sacrificial Egg
}

\author{
Meditações sobre The Sacrificial Egg
}

\section{Sam Okoth Opondo}

\begin{abstract}
This text-mediated meditation on colonialism, ethnological reason, and the dynamics of encounter and recognition proceeds through a reading of Chinua Achebe's short story The Sacrificial Egg alongside a series of philosophical, fictional, and ethnological texts. Heeding how Achebe treats questions of conversion, immunity/community, the passage of beliefs , curses, and knowledge from one generation to another (or even to a strangers), I also offer some reflections on the politics of knowledge, genre, citation/attribution, and ethics of co-habitation.
\end{abstract}

\section{Keywords}

Meditation; Ethnological Reason; Entanglement.

\section{Resumo}

Esta meditação mediada por texto sobre o colonialismo, a razão etnológica e a dinâmica do encontro e reconhecimento prossegue através da leitura do conto The Sacrificial Egg, de Chinua Acheb, juntamente com uma série de textos filosóficos, ficcionais e etnológicos. Atentando a como Achebe trata as questôes de conversão, imunidade/comunidade, a passagem de crenças, maldições e conhecimento de uma geração para outra (ou mesmo para estranhos), também ofereço algumas reflexóes sobre a política do conhecimento, gênero, citação/atribuição, e a ética da coabitação.

\section{Palavras-chave}

Meditação; Razão Etnológica; Emaranhamento. 
"The world is an egg, but the egg itself is a staged theatre: a theatre in which the roles dominate the actors, the spaces dominate the roles, and the ideas dominate the spaces." Gilles Deleuze (Difference and Repetition, 1994, p. 216)

When read without proper attribution to its philosopher author, the epigraph above reads somewhat like an advertisement for the yoni Jade Eggs sold through Gwyneth Paltrow's Goop lifestyle and wellness company. As with most practices that transform cultural artefacts into alienable products for aspirational self-optimization, wellness, and healing today, the selling point for Goop's Jade Eggs revolves around the debunked marketing claim that the eggs were "the strictly guarded secret of Chinese royalty in antiquity," that could be used to enhance sexual and other energies today (GUNTER; PARCAK, 2019). Here, the turn to ancient knowledges and practices, the turn to the culture of the other, allows Goop to question Western biomedicine while at the same time cultivating an idealized image of the Western self. It's appeal to alternative lifestyles and knowledges are simultaneously neoliberal and erotic in their activation of an exotic and esoteric spirit of capitalism. A spirit that, contrary to its claims about "shifting old paradigms and starting new conversations," works to sustain a stable "white mythology" (DERRIDA; MOORE, 1974, P. 12).

That noted, I want to begin my text-mediated meditation on The Sacrificial Egg (ACHEBE, 1991) by stating that it is not part of an esoteric or erotic practice. Inspired by Chinua Achebe's short story by the same title, my mediation on how actors, roles, ideas, and spaces interact with each other on a "staged theatre" proceeds through some brief remarks on philosophy, colonialism, and ethnological reason. By reading African literature and philosophy side-by-side, the meditation explores cultural entanglements and an 'economy of flows' that puts familiar "questioners into question" while questioning the partitioning and orderings of knowledges, worlds, and ultimately, the genres of Man characteristic of modernity/coloniality (MALDONADO-TORRES, 2016, p, 25).

In Achebe's The Sacrificial Egg, we encounter the workings of what Nelson Maldonado-Torres calls "metaphysical catastrophe." Julius Obi, the story's protagonist, is a mission-educated young man who moves to the town of Umuru where he now works as a clerk in "the all-powerful European trading company." Located right 
next to the local Nkwo market (named after the Nkwo market day even though trading has now spilled over to other days - Eke, Oye, and Afo), the elevated position of the trading office allows Julius a privileged vantage point from which he observes " the great market on the bank of River Niger" and it's changing rhythms. As Julius observes the new rhythms in this space of multiple encounters, he is also a witness to, and subject of the colonial metaphysical catastrophe that has transformed the "meaning and relation of basic areas of thinking and being, particularly the self and the other, along with temporality and spatiality, among other key concepts in the basic infrastructure that constitutes our human world" (MALDONADO-TORRES, 2016, P. 11). As Achebe puts it, colonial rule and "the coming of civilization," had turned the town into a busy space characterized by the flow of strange people, strange things, and strange beings. The physical and metaphysical rapture manifests in ecological interruptions and everyday estrangement as the "young sons and daughters of Umuru soil, encouraged by schools and churches, were behaving no better than the strangers."

Achebe's short story intrigues me, moreover, because it is a story about rhythms, cross-roads, encounters, milieus, and waiting. And waiting, as V.Y. Mudimbe (2000, p. 23-24) puts it, "is an absolute meditation". Unlike calculative thinking that seeks to map the best path to take in order to solve crises, meditative thinking is a more patient practice. It allows us to join the fictional character Julius as he waits and contemplates his own fate and that of a community exposed to new ways of being, compromised immunities, foreign bodies, and the dynamics of exposure and enclosure. Whereas the market and town at the beginning of the story had been exposed to a foreign colonizing "civilization" that turned it into a "busy sprawling, crowded and dirty river port," by the end of the story, a small pox epidemic - characterized by a visit by the evil deity Kitikpa - had "put an end to the coming and going between neighbors and between villages." As both god and disease-carrying foreign body, Kitikpa also interrupted the community's desire. In his indiscriminate movement between believers and non-believers, he effectively cut villages off from each other by 'decorating' the bodies of the living and the dead who were now intimately connected to each other. Though he remains uninfected by the disease, Julius is still subjected to the prevailing immunitary order. His physical movement and affect is constrained as he cannot visit the lady he intends to marry (Janet) who, like most of the community, is now afflicted by the markings of a god who kills and scars as he moves through Umuru demanding "the sacrifice that inhabitants owed the gods of the soil." 
While Achebe's literary text may be read for its cultural insights, it primarily points to how life and gnosis in Umuru is being subjected to a multiplicity of forces. ${ }^{1}$ Acting as an aesthetic, rather than purely ethnographic or psychological subject, Julius navigates and negotiates his estrangement and presence in a colonized, modernizing, yet deeply enchanted world. For instance, the story begins with a character whose primary mode of taking in the world is scopic /optic ( Julius sits gazing at a typewriter and then walks to the window overlooking the great market to observe its rhythms). As the story progresses, his encounter with, and reception of the world becomes more haptic. His fate, it seems, is determined by the work of his feet and what he fails to see rather than competences derived from how he reads and sees the world or himself. As the small pox epidemic ravages Umuru, Julius's lives in fear of both the biological markings that the disease leaves on one's skin and the curse that might have marked him after he accidentally "stepped on an egg offered in sacrifice by someone oppressed by misfortune" who had placed it at the cross-roads. That Janet and her mother (Ma) both get small pox creates further distance between people who had hitherto been proximate and intimate thus calling into question the narrative of self and world that Julius had crafted for himself as an educated convert.

The brevity of Achebe's story does not stand in the way of effectively depicting the passage of time and the fatalistic deities and colonial forces of progress that had turned Umuru from a small village into "a busy, sprawling, crowded, and dirty river port." By drawing the reader's attention to entanglement of human and more-thanhuman beings, The Sacrificial Egg paints a vivid picture of a society where syncretic forms of knowledge and practices accompany colonial governance, conversion, and disruption of everyday life in Umuru. For instance, we witness the physical and psychological emptiness and terror that fills Julius's days as a result of the small pox outbreak but also the uncertainty that haunts a character who believes his Christianity and education has freed him from traditional taboos in ways that impact on his romantic and professional relations.

\footnotetext{
${ }^{1}$ V.Y. Mudimbe's Invention of Africa provides a wider scope of African knowledge by focusing on gnosis rather than epistemology. More specifically, Mudimbe notes that gnosis which means "seeking to know, inquiry, methods of knowing, investigation and even acquaintance with someone and higher and esoteric knowledge" should be "differentiated from doxa or opinion, and one the other hand cannot be confused with episteme, understood as both science and general intellectual configuration" (Mudimbe, 1988, p. 9).
} 
Unlike Achebe's widely anthologized essay , An Image of Africa: Racism in Conrad's Heart of Darkness where Achebe carries out a critique of Conrad's negative representation of Africans and the absences and comparative mode that underlines it, The Sacrificial Egg reads the colonial world through a an ethic and narrative structure that refuses the flattening out of multiplicity or the immediacy of the traveler and their native informant (ACHEBE, 2016). Consider the following passages from the essay where Achebe provides a contrapuntal reading of the Rivers Thames and Congo as they appear in Conrad's work and the ways in which such comparison, even though it is mobilized for humanitarian purposes, remains deeply racist. It also embodies an imperial aesthetic where everything fits in its proper place and Africans are for the most part mute and fragmented embodiment of negativity:

The book opens on the River Thames, tranquil, resting peacefully "at the decline of day after ages of good service done to the race that peopled its banks." But the actual story will take place on the River Congo, the very antithesis of the Thames. The River Congo is quite decidedly not a River Emeritus. It has rendered no service and enjoys no old-age pension. We are told that "going up that river was like travelling back to the earliest beginning of the world." Is Conrad saying then that these two rivers are very different, one good, the other bad? Yes, but that is not the real point. It is not the differentness that worries Conrad but the lurking hint of kinship, of common ancestry. For the Thames too "has been one of the dark places of the earth." It conquered its darkness, of course, and is now in daylight and at peace. But if it were to visit its primordial relative, the Congo, it would run the terrible risk of hearing grotesque echoes of its own forgotten darkness, and falling victim to an avenging recrudescence of the mindless frenzy of the first beginnings. These suggestive echoes comprise Conrad's famed evocation of the African atmosphere in Heart of Darkness. In the final consideration, his method amounts to no more than a steady, ponderous, fake-ritualistic repetition of two antithetical sentences, one about silence and the other about frenzy (ACHEBE, 2016, p. 14).

The above inter-articulation of knowledges and worlds through literature is sometimes stifled by orders of purification that, though permeable, still enact forms of selection that determine how African knowledges, beings, and things flow on a planetary scale. Unlike the Conradian representation of Africa as Europe's other world, The Sacrificial Egg ventures into the other worldly to facilitate a side-by-side reading of the multiplicity of African worlds while carrying out a critique of Europe and the 
modern/colonial world at large. Here, Achebe's short story, even more than his essay on Conrad, enacts the contrapuntality that Edward Said calls for in his critical reading of Achebe's essay on Conrad. According to Said, one needs to see these writers as " figures whose writing travels across temporal, cultural and ideological boundaries in unforeseen ways to emerge as part of a new ensemble along with later history and subsequent art" (BOLLAS; ROSE; SAID, 2014, p. 24). The multiple worlds that hatch and emerge out of Achebe's short story stage an encounter between a multiplicity of forces while illustrating how these forces act on the same person, place, and community simultaneously. In so doing, Achebe's writing on what appears to be a colonial society that is at once 'traditional' and 'modern,' reveals how ethnological reason often denies an originary syncrectism in the cultures it focuses on. ${ }^{2}$ As the story exposes the 'unreasonable' repressions, alienation, and anxieties that lie at the center of enlightened rationalities and colonial reason, it also summons us to meditate more deeply on the forms of co-habitation that precede, exceed, or are imposed and erased by colonial forms.

As one meditates on the narrative voice, untranslated terms, and interrupted gaze in the short story, it becomes clear that these literary devices perform a kind of refusal of the ethnological desire to fully know the other primarily through the mediation of the familiar figure of the native informant. If anything, Achebe joins theorists like Gayatri Spivak who have for a long time questioned the foreclosure of the native informant in western epistemology and the sanctioned ignorance and "marking of the impossibility of [the] ethical relation" arising from such foreclosure (SPIVAK, 1999, p. 6). As the readers follow or sit with Julius, the story goes further to reveal the formation of both the figure of the native and the informant while interrupting the desire to fully an ethnic other who we quickly recognize is a conflicted stranger to himself. In emphasizing his encounter with the egg, Kitipka, the river, Umuru, and other human and more-than human beings, the story displaces the ethnic other and in his place, we meet an ethical other while ethnology is disturbed by a coloniallymediated ethology. As M. Jacqui Alexander artfully puts it in her meditations on Pedagogies of Crossing, attention to this spiritual domain involves refusing and reassembling the 'postmodern' presentation of the sacred as traditional. It is a

\footnotetext{
${ }^{2}$ For Amselle, ethnological thinking/reason means the following: A "continuity-breaking procedure that extracts, refines, and classifies with the intention of isolating types, whether in the realm of politics (state society versus stateless society). Economics (self-sufficient versus market economy), religion (paganism versus Islam), ethnicity, or culture.) (AMSELLE, 1998, p. 1).
} 
pedagogical reassembling that revisits familiar cross-roads and knows them anew through its refusal of the "divides between the Sacred and the secular, the embodied and the disembodied" thus enabling one to embrace relations, knowledges, and sensibilities that "fit neither easily nor neatly into those domains that have been imprisoned within modernity's secular episteme" (LAFRANCE, 2008, p.7).

\section{II}

Such crossing also requires an attunement to how familiar signs are ordered and over-coded, as well as the world of meanings, knowledge, and relations that underwrite them. As V.Y Mudimbe, Johannes Fabian, Jean Loup-Amselle, Michel Foucault, and others remind us, the meanings and relations such as the ones in Achebe's Sacrificial Egg are often the privileged objects of ethnological reason. As a world making /unmaking practice predicated on the comparison of cultures (according to a Western grid), ethnology can either elevate African belief and thought "systems to the level of their Western homologues" or present them as "closed structures" that can only speak of African specificities and interiorities. (AMSELLE, 1998, p.17). It can also be the producer of what Walter Mignolo calls colonial difference. This boundarymarking practice then proceeds to determine what is or is not philosophy, properly human, and even diplomatic. In so far as philosophy is concerned, colonial difference subjects the knowledge of the other to the double process of "assimilation (Arabic or African philosophy is so similar to Western philosophy that it makes no contribution) and marginalization (it is so different that its credentials will always be in doubt)" (MIGNOLO, 1999, p. 36). Either way, Africans are located "allochronically" through textual projections that put them in another time. This time of the other is either associated with earlier periods of individual life (childhood) or those of human history (primitivism) thus legitimizing anthropological, humanitarian, developmental, and pedagogical interventions. ${ }^{3}$ Ultimately, the denial of coevalness disavows the mutual constitution of colonial and modern worlds and the deeper ethical relations and obligations we have towards the human and more-than-human beings with whom we share the planet and hopefully, the future.

The denial of coevalness, the obsession question of origins, negative interpretation of Africanness, and ethnological reason come together to form a mode of thought and relation that assumes that African thought is cryptogenic (of unknown

\footnotetext{
3 For more on allochronicity and denial of coevalness, see Fabian (1983).
} 
origin), non-existent, or can be understood only by attributing its insights to the workings of known external forces. In an extended commentary on the "series of oppositions and levels of classification of humans" that extol the idea of "African inferiority", Mudimbe looks at a multiple sites where a mode of thought that makes the possibility of African thought unthinkable persists:

[...] Explorers just brought new proofs which could explicate "African inferiority." Since Africans could produce nothing of value; the technique of Yoruba statuary must have come from Egyptians; Benin art must be a Portuguese creation; the architectural achievement of Zimbabwe was due to Arab technicians; and Hausa and Buganda statecraft were inventions of white invaders (MUDIMBE, 1988, p. 13).

Turning to the work of M. Griaule on the "complexity of Dogon astronomical knowledge and its symbolism," Mudimbe notes how Carl Sagan, the American astronomer and cosmologist, took on "the task of checking the validity of Dogon cosmology." Amazed by the Dogon's astronomical knowledge, Sagan speculates about the insights found in this "prescientific" African society and attributes their source of knowledge to other societies: "I picture a Gallic visitor to the Dogon people ... He may have been a diplomat, an explorer, an adventurer or an early anthropologist ...." who , as most travelers are wont to do in their encounters with cultural others, makes inquiries into the Dogon system of knowledge and "exchanges a spectacular myth for a routine one" (MUDIMBE, 1988, p. 14). According to Sagan, the European visitor plants the astronomical knowledge in the Dogon and it is then retold as part of their mythology such that "when Marcel Griaule makes mythological inquiries in the 1930s and 1940s, he has his own European Sirius myth played back to him" (MUDIMBE, 1988, p. 15). In his reading of Sagan and other discourses on African societies and their knowledge, Mudimbe identifies "bad faith" (in the Sartrean sense)", the "power of a will to truth" and "an epistemological ethnocentrism; namely, the belief that scientifically there is nothing to be learned from "them" unless it is already "ours" or comes from us" (MUDIMBE, 1988, p. 15).

According to Mudimbe, focusing on African gnosis reveals the limits of anthropology as a system of knowledge while illustrating the invention of "traditional" African philosophies within those Western discourses that purport to represent them (MUDIMBE, 1988, p. 186). To decolonize knowledge therefore, demands that we do 
more than engage in purification exercises that seek to restore a primordial story, or return to a time of original Africanness and authenticity as we often find within the frames of ethnological reason. More specifically, Mudimbe's Idea of Africa illustrates how ethnological reason "always extracts elements from their context, aestheticizes them, and then uses their supposed differences for classifying types of political, economic, or religious ensembles" (MUDIMBE, 1994, p. 52) That is, ethnology, as a mode of comparing and contrasting cultures is at once epistemological and ontological. It "establishes a relation between the technical development of material arts and mentalities" which is used to produce forms of knowledge that confirm the inferiority of certain peoples or marks them as being capable of only speaking about their particularities, mimicking, or being ventriloquized by external others (MUDIMBE, 1999 , p. 55) With the culture of the other as its primary referent, ethnology is deeply invested in the politics and laws of genre and by extension, the genres of Man. It involves the comparison of cultures and concepts of Man not only across space, but also in time thus establishing a deep relationship with history and psychoanalysis (FOUCAULT, 2012, p. 407). Evidence of this entanglement between orders of knowledge is found in Michel Foucault's critique of ethnology in his The Order of Things especially the last section of a chapter aptly titled 'Man and his Doubles' where Foucault speaks of philosophy falling into a deep 'anthropological sleep' (FOUCAULT, 2012, p. 371).

Further evidence of philosophy's anthropological sleep and its uses of the (African) other is illustrated in the third chapter of Gilles Deleuze and Felix Guattari's Anti-Oedipus where we see its relationship to ethnology and psychoanalysis. ${ }^{4}$ As Deleuze and Guattari recombine and shuffle orders of knowledge, they also invite us to read and relate otherwise. Within this recombinant order of things, books and thought takes on new meaning such that "the great book of modern ethnology is not so much Mauss's The Gift as Nietzsche's On the Genealogy of Morals." In part, this is because the Genealogy, "is an attempt - and a success without equal - at interpreting primitive economy in terms of debt, in the debtor-creditor relationship." Now recast as an ethnological text, Genealogy brings to the fore the "problem of inscription, of coding, of marking" through which Man "constitutes himself" and the

\footnotetext{
${ }^{4}$ For more on the relationship between psychoanalysis, colonialism, and ethnological reason, see Bollas, Rose and Said (2014) or Nandy (2000). For an 'analysis' of race and psychoanalysis, see Spillers (1996).
} 
repression that makes it possible to have certain memories, collectivities, and collective memories (DELEUZE; GUATARI, 1998, p. 190).

Earlier on in the same chapter, Deleuze and Guattari already wrote at length about Marcel Grauile's ethnology of the Dogon (The Pale Fox). Their engagement with the ethnological text here enables them to use the Dogon's foundational myth of the cosmic egg to escape oedipal familialism. ${ }^{5}$ Through the Dogon's ambiguous signs and relations based on "the placenta, which has become the earth, the unengendered, the full body of anti-production where the organs partial objects of a sacrificed Nommo are attached," they also come to question the organization of the body (DELEUZE; GUATARI, 1998, p. 158). Ultimately, the Dogon myth "gets the same epistemological value as the Oedipus myth" and with the passage from ethnology to philosophy, the Dogon egg become the basis of their well-known concept, the Body Without Organs (OOSTERLING, 1989). This knowledge relay is well illustrated in their chapter "How do you Make Yourself a Body without Organs" in A Thousand Plateaus where they proclaim that the Body Without Organs is an egg (DELEUZE; GUATARI, 1998, p. 164).

Beyond myth, ethnology, and philosophy, the worlds and planes of Deleuzian eggs multiply as we move through texts like his Method of Dramatization, and Difference and Repetition where he turns to embryology to illustrate how, just " as with grains of wheat", " no two eggs are identical." Not only do they all have " intensities," eggs, if you like, become a model. Putting the biological egg side-by-side with the schizophrenic egg, and the cosmic egg, Deleuze and Guattari destabilize the family drama and colonial order of psychoanalysis by turning to another science of the other (DELEUZE; PATTON, 1994, p. 216). Within this anti-oedipal scheme of things, Oedipus is revealed to be more than a mere psychoanalytic construct. Psychoanalysis is the "cure from which we need a cure" for Oedipus is, as Deleuze and Guattari illustrate, " a figurehead of imperialism, colonization pursued by other means, it is the interior colony,...it is our intimate colonial education" (DELEUZE; GUATARI, 1998, p. 22).

\footnotetext{
${ }^{5}$ According to Deleuze and Guattari (1998, p. 55), Freud "oedipalized, and closed the familial triangle over the entire unconscious" such that the "unconscious ceases to be what it is-- a factory, a workshop-to become a theater, a scene and its staging".
} 
III

Unfortunately, such a scrambling of psychoanalysis or modern philosophy and the creation of concepts that accompanies it does not translate to an ethical relation with the Dogon or other colonial subjects. In familiar sacrificial fashion, an idiom, affect, or world, central to the formation of an Idea or concept is set apart or taken out of circulation, citation, and use by an order of knowledge that comes to supplant or appropriate its signs thus stifling thought and the ethical encounters. At stake here is the contestation over whose knowledge or thought can be said to exceed the particularities of a given culture and how these knowledge claims inflect how we think about humanity, universality, or even planetarity.

Whereas a short story like Achebe's Sacrificial Egg supplies us with some insights into the workings of colonialism or a glimpse into the culture or lifeworld of the Igbo under colonial rule, the force of this literary text lies in its capacity to affectively rupture and call attention to a life, a lifeworld, and the multiplicity of forces and anxieties emerging from cross-road encounters. Julius' world, as we come to see, is haunted by the interplay of what he thinks he knows and the force of that which he does not or cannot know. Owing to the worlds that come to overlap or are interrupted at the cross-roads, the short story moves into an economy of desire and flows of bodies that transforms the dynamics of community and immunity in Umuru. In its condensation and dispersal of time, the short story form effectively turns Julius from being an ethnographic subject (who supplies us with the truths of the Igbo community) into a conceptual persona (who provokes thought about modernity, coloniality, immunity, humanity, and the force of the unknown).

Here, sitting meditatively with the protagonist of The Sacrificial Egg (as if one were waiting for it to hatch) allows for a philo-poetic reading of the multiple idioms and worlds that animate the text. ${ }^{6}$ Through such an interferential reading, the meditation acts as a critical genealogy of the mediation of estrangement that makes unlikely connections between texts and worlds in ways that question philosophy, literature, and ethnological reason. ${ }^{7}$ Not only does it combine the ethnological or mythological object with the philosophical concept (Dogon egg), it also the reads a critical philosophical text as a kind of overlooked or forgotten ethnological text (Nietzsche's Genealogy of Morals ). As such, the text-mediated meditation on philosophy and ethnological reason is also a genealogy. Something that Michel

\footnotetext{
${ }^{6}$ For a detailed treatment of philopoesis, see Casarino (2002). Also see Elza (2011).

7 See Der Derian James (1987).
} 
Foucault tells us "operates on a field of entangled and confused parchments, on documents that have been scratched over and recopied many times" thus revealing their ruses as well as their unacknowledged entanglements. ${ }^{8}$

And here is the paradox: as one meditates on philosophy's anthropological slumber, one cannot help but be philosophical while grappling with the " complexity of integrating at least two notions that may at first not seem compatible-namely, reason and culture" (GORDON, 2010, p. 196). The specter of ethnological reason haunts the familiar cultures of philosophy (a Euro-centric ethnophilosophy) and, even where it is unacknowledged, the appropriative reading of those peoples and cultures who colonialism considered not to have a history, reason, or a philosophy. To supply a different way of reading the intersection of, and passage of knowledges between different worlds, Souleymanne Bachir Diagne illustrates how a multiplication of idioms and thought can also be arrived at by pluralizing the trajectory of the translatio studiorum (transfer of knowledge/learning). Such a multiplication of trajectories gives us a geography and history of philosophy as well as the philosophy of history where " philosophy has passed through many languages other than Greek, Latin, and German, and followed many routes, which started from Baghdad, Cordoba, and led to Fez and Timbuktu" (DIAGNE, 2020, p. 22-23). It also allows us to go beyond the citational practices and the deep intellectual slumber arising from disciplinary methods, identity investments, or disciplining of thought that makes it difficult for us to ask why we don't know what we don't know. As the opening illustration from Goop reveals, a turn to any-alternative-whatever to the hegemonic mode is an insufficient and sometimes dangerous intervention through which familiar modes sneak back in the guise of the unfamiliar or the other. To excavate, decolonize, and unscramble the familiar worlds and knowledges, it is important that one composes an ethic and awareness of how diverse fields of knowledge and worlds para-cite and feed off of each other knowingly and unknowingly. How such para-citation are sometimes colonial and often times, exceed the modern/colonial frame and its impositions and silences. This being the case, philosophy, as the creation of concepts, will have to come to terms not only with the great anthropological slumber that animates it, but also its own racialized forgetfulness. A forgetfulness which, as Siba Grovogui puts it, works through cryptomnesia — "the

\footnotetext{
${ }^{8}$ See Michel Foucault (1984).
} 
belief that a thought is novel when in fact it is the return of a memory that has been forgotten or repressed." .

\section{- Sam Okoth Opondo é Professor Associado de Ciência Política e Estudos Africanos no Vassar College, N.Y. E-mail: saopondo@vassar.edu.}

\section{Referências}

ACHEBE, Chinua. An image of Africa: racism in Conrad's Heart of Darkness. The Massachusetts Review, v. 57, n. 1, p. 14-27, 2016.

ACHEBE, Chinua. The sacrificial egg. In: ACHEBE, Chinua. Girls at war and other stories. Great Britain; New York: Anchor Books, 1991. p. 43-49.

AMSELLE, Jean-Loup. Mestizo Logics. Anthropology of Identity in Africa and Elsewhere. Stanford: Stanford U. P., 1998.

BOLLAS, Christopher; ROSE, Jacqueline; SAID, Edward. Freud and the non-European. London: Verso, 2014.

CASARINO, Cesare. Philopoesis: A Theoretico-Methodological Manifesto. Boundary, v. 29, n. 1, p. 65-96, 2002.

CROCKFORD, Susannah. What Do Jade Eggs Tell Us about the Category "Esotericism"? Spirituality, Neoliberalism, Secrecy, and Commodities. New Approaches to the Study of Esotericism, v. 17, n. 1, p. 201-226, 2021.

DELEUZE, Gilles; GUATTARI, Félix. Anti-oedipus: Capitalism and Schizophrenia. Minneapolis: University of Minnesota Press, 1998.

DELEUZE, Gilles; PATTON, Paul. Difference and Repetition. New York: Columbia University Press, 1994.

DER DERIAN, James. On Diplomacy, A Genealogy of Western Estrangement. New York: Basil Blackwell, 1987.

DERRIDA, Jacques; MOORE, F. C. T.. White Mythology: Metaphor in the Text of Philosophy. New Literary History, v. 6, n. 1, p. 5-74, 1974.

DIAGNE, Souleymane. On the Universal and Universalism. In: DIAGNE, Souleymane et al. In Search of Africa(s): Universalism and Decolonial Thought. Cambridge/Medford: Polity Press, 2020 p. 22-23.

\footnotetext{
${ }^{9}$ I am grateful to Siba Grovogui for outlining the workings of cryptomnesia and its implications for the knowledge claims during a personal communication that took place on May $25^{\text {th }} 2021$.
} 
ELZA, Daniela. Pedagogy of the Imagination: Philo-poesis, Non verifiable Truths, and Other Existential Celebrations. PhD Dissertation. Burnaby, B.C: Simon Fraser University, 2011.

FABIAN, Johannes. Time and the Other: How Anthropology Makes its Object, New York: Columbia University Press, 1983.

FOUCAULT, Michel. Nietzsche, genealogy, history. In: FOUCAULT, Michel; RABINOW, Paul. The Foucault Reader. New York: Pantheon Books, 1984. p.76-100.

FOUCAULT, Michel. The Order of Things. Hoboken: Taylor \& Francis, 2012.

GORDON, Lewis R. Theory in black: Teleological suspensions in philosophy of culture. Qui Parle: Critical Humanities and Social Sciences, v. 18, n. 2, p. 193-214, 2010.

GUNTER, Jennifer; PARCAK, Sarah. Vaginal Jade Eggs: Ancient Chinese Practice or Modern Marketing Myth?. Female Pelvic Medicine \& Reconstructive Surgery, v. 25, n. 1, p. 1-2, 2019.

LAFRANCE, Laure E. M. Jacqui Alexander. Pedagogies of Crossing: Meditations of Feminism, Sexual Politics, Memory and the Sacred. Atlantis: Critical Studies in Gender, Culture \& Social Justice, v. 32, n. 2, p. 160-162, 2008.

MALDONADO-TORRES, Nelson. Outline of ten theses on coloniality and decoloniality. 2016. Disponível em: <http://fondation-frantzfanon.com/wp-content/uploads/2018/10/maldonadotorres_outline_of_ten_theses-10.23.16.pdf> Acesso em: 10 de outubro de 2021.

MIGNOLO, Walter D. Philosophy and the colonial difference. Philosophy Today, v. 43, n. Supplement, p. 36-41, 1999.

MUDIMBE, V. Y.. The Invention of Africa. Gnosis, Philosophy and the Order of Knowledge. p. 44$97,1988$.

MUDIMBE, Valentin Y. The politics of war: a meditation. In: BRAATHEN, Einar; BØÅS, Morten; SÆTHER, Gjermund (org.). Ethnicity Kills? Palgrave Macmillan: London, 2000. p. 23-34.

NANDY, Ashis. The Savage Freud: And Other Essays on Possible and Retrievable Selves. Delhi: Oxford University Press, 2000.

OOSTERLING, Henk. Oedipus and the Dogon: Myth of Modernity interrogated. In: KIMMERLE, Heinz (org.) I, We and the Body. Amsterdam: Grüner, 1989, p. 27-45.

SPILLERS, Hortense J. All the Things You Could Be by Now If Sigmund Freud's Wife Was Your Mother: Psychoanalysis and Race. Critical Inquiry, v. 22, n. 4, p. 710-734, 1996.

SPIVAK, Gayatri Chakravorty. A critique of postcolonial reason: Toward a history of the vanishing present. Cambridge: Harvard university press, 1999.

Texto recebido em 14 de novembro de 2021. Aprovado em 17 de novembro de 2021. 